\title{
PENGARUH KINERJA KEUANGAN, ECONOMIC VALUE ADDED DAN MARKET VALUE ADDED TERHADAP RETURN SAHAM PERUSAHAAN MANUFAKTUR
}

\section{EFFECT OF FINANCIAL PERFORMANCE, ECONOMIC VALUE ADDED, AND MARKET VALUE ADDED TO STOCK RETURN OF MANUFACTURING COMPANY}

\author{
Arisky Andrinaldo', Husaini' ${ }^{2}$, Darman Usman ${ }^{3}$, Ronal Aprianto ${ }^{4}$ \\ Universitas Bina Insan Lubuklinggau ${ }^{1,4}$ \\ Universitas Bengkulu ${ }^{2,3}$ \\ arisky.andrinaldo@gmail.com ${ }^{1}$
}

\begin{abstract}
Dalam melakukan investasi di pasa modal, seorang investor perlu mempertimbangkan tingkat keuntungan (Return) yang diharapkan. Penelitian ini bertujuan menguji apakah kinerja keuangan (net income, NOPAT, EPS), EVA, dan MVA berpengaruh signifikan terhadap return saham. Objek penelitian ini ialah Perusahaan Manufaktur yang terdaftar pada Tahun 2013 hingga 2017. Penelitian ini menggunakan data sekunder dengan purposive sampling method. Data yang didapatkan pada penelitian ini ialah sebanyak 52 sampel perusahaan. Analysis method data penelitian ini ialah regresi linier berganda. Hasil penelitian menunjukkan bahwa net income dan market value added berpengaruh signifikan terhadap return saham, dan earning per share serta economic value added tidak berpengaruh signifikan terhadap return saham. Selain itu, earning per share dan economic value added tidak berpengaruh signifikan terhadap return saham. Berdasarkan hasil penelitian ini, teori sinyal mempengaruhi informasi yang dihasilkan melalui net income dan market value added kepada investor untuk memberikan respon atas sinyal yang diberikan dalam pengambilan keputusan berinvestasi agar menghasilkan return saham yang diharapkan. Penelitian selanjutnya diharapkan untuk menambah periode penelitian dan variabel bebas lainnya yang mempengaruhi return saham.
\end{abstract}

Keywords: Stock Returns, Net Income, Earning Per Share, Economic Value Added, and Market Value Added

\begin{abstract}
ABSTRAK
Dalam melakukan investasi di pasar modal, seorang investor perlu mempertimbangkan tingkat keuntungan (Return) yang diharapkan. Penelitian ini bertujuan menguji apakah kinerja keuangan (net income, NOPAT, EPS), EVA, dan MVA berpengaruh signifikan terhadap return saham. Objek penelitian ini ialah Perusahaan Manufaktur yang terdaftar pada Tahun 2013 hingga 2017. Penelitian ini menggunakan data sekunder dengan purposive sampling method. Data yang didapatkan pada penelitian ini ialah sebanyak 52 sampel perusahaan. Metode analisis data penelitian ini ialah regresi linier berganda. Hasil penelitian menunjukkan bahwa net income dan market value added berpengaruh signifikan terhadap return saham, dan earning per share serta economic value added tidak berpengaruh signifikan terhadap return saham. Selain itu, earning per share dan economic value added tidak berpengaruh signifikan terhadap return saham.
\end{abstract}


Berdasarkan hasil penelitian ini, teori sinyal mempengaruhi informasi yang dihasilkan melalui net income dan market value added kepada investor untuk memberikan respon atas sinyal yang diberikan dalam pengambilan keputusan berinvestasi agar menghasilkan return saham yang diharapkan. Penelitian selanjutnya diharapkan untuk menambah periode penelitian dan variabel bebas lainnya yang mempengaruhi return saham.

Kata Kunci : Return Saham, Net Income, Earning Per Share, Economic Value Added, dan Market Value Added

\section{PENDAHULUAN}

Investasi dapat dilakukan melalui sarana yang beragam salah satunya yaitu dengan berinvestasi di pasar modal. Makna Pasar modal yaitu tempat terjadinya penawaran dan permintaan atas instrumen keuangan jangka panjang. Instrumen pasar modal yang diterbitkan dan digunakan oleh perusahaan dan para investor dalam berinvestasi saham. Dalam melakukan investasi di pasar modal, seorang investor perlu mempertimbangkan dua faktor, yaitu tingkat keuntungan (Return) yang diharapkan dan risiko yang mungkin terjadi. The concept of risk is inseparable from the return, because investors always expect a rate of return that matches each risk they face. Risiko yang akan di hadapi investor, diantaranya capital loss dan kemungkinan perusahaan dilikuidasi.

Return saham dapat diartikan sebagai keuntungan atau kerugian yang diperoleh dalam investasi pada suatu periode tertentu. Umumnya, semakin tinggirisiko yang harus ditanggung, maka potensi nilai Return atau hasil juga akan semakin tinggi. Return dapat berupa Return realisasian yang sudah terjadi dan Return ekspetasi yang belum terjadi tetapi diharapkan akan tercapai dimasa mendatang (Amiyulianty \& Elsa, 2016).

Untuk mengukur kinerja keuangan, maka diperlukan rasio keuangan guna membantu mengevaluasi dan mengidentifikasi beberapa kekuatan dan kelemahan atas kinerja keuangan perusahaan dalam periode tertentu. Seperti net income (laba bersih) dalam kegiatan jual beli saham, informasi keuangan khususnya net income (laba bersih) suatu perusahaan dapat menjadi salah satu cerminan atau tolak ukur seorang investor untuk mengambil keputusannya berinvestasi (Hery, 2016). Pengumuman informasi akuntansi khususnya informasi net income (laba bersih) akan memberikan sinyal bahwa perusahaan mempunyai prospek yang baik di masa yang akan datang dan mengestimasi kemampuan perusahaan dalam menghasilkan laba dan Return saham dimasa yang akan datang.

Berbagai indikator kinerja seperti yang dijelaskan di atas mulai dari Rasio Net Income, NOPAT, dan EPS yang memiliki pengaruh terhadap Return saham (Paradiba \& Nainggolan 2015; Wahyu \& Khairunnisa 2017). Akan tetapi ada sejumlah alternatif yang dapat memberikan penilaian kinerja serta informasi akan Return saham yang didapat nantinya, diantaranya Economic Value Added dan Market Value Added. Kedua pendekatan ini merupakan pendekatan alternatif untuk sebagai ukuran Net Income yang mengukur kinerja manajerial dalam suatu periode tertentu. Beberapa penelitian terdahulu menunjukkan bahwa Net Income berpengaruh signifikan terhadap Return Saham (Rahmawati, 2016; Septiana \& Wahyuati, 2016). Perusahaan yang 
menghasilkan laba semakin besar, maka secara teoritis perusahaan itu akan mampu membagikan dividen yang semakin besar. Dengan meningkatnya dividen yang diterima oleh investor, maka Return yang diterima oleh investor juga akan meningkat (Sugianto \& Nugraha, 2017).

Economic Value Added (EVA) adalah metode untuk mengukur kemampuan entitas guna mewujudkan nilai yang diukur dari tingkat laba ekonomi yang diperoleh (Husnan et al., 2015). Economic Value Added merupakan nilai tambah ekonomis yang mengukur NOPAT dikurangi dengan biaya kapital sehingga mengahasilkan imbal hasil atau Return (Jariah, 2018). Return tersebut akan menjadi sinyal kepada investor dalam menambah investasi dengan harapan Return yang diberikan akan meningkat atas nilai tambah ekonomi tersebut dan sebaliknya jika sinyal diberikan tidak dapat menyakinkan nya. Beberapa hasil penelitian menunjukkan bahwa variabel economic value added berpengaruh signifikan terhadap Return Saham (Ibrahim et al., 2018; Husnan et al., 2017).

Market Value Added (MVA) adalah perbedaan antara nilai pasar perusahaan dan nilai buku saham. Market value added merupakan perbedaan nilai pasar perusahaan yang didapat dari harga saham akhir periode dan jumlah saham beredar (entitas) dikurangi keseluruhan modal investasi sehingga akan ada sinyal yang diberikan atas perhitungan tersebut, karena melihat nilai pasar perusahaan yang bertambah dari harga saham yang naik atau return saham pun akan meningkat, sehingga sinyal tersebut akan menjadi pertimbangan investor dalam menanamkan modal investasi dalam pasar modal. Hasil penelitian Nakhei (2016) menunjukkan bahwa variabel market value added berpengaruh signifikan terhadap Return Saham. Oleh karena itu, market value added dapat memberikan sinyal kepada investor atas nilai pasar perusahaan terhadap Return Saham, karena market value added mencerminkan ekspektasi pasar terhadap perusahaan di masa datang dan sebagai gambaran seberapa besar tingkat kemakmuran yang diciptakan, sehingga akan memberikan pengaruh kepada investor dalam pengambilan keputusan dengan harapan Return Saham yang dihasilkan perusahaan (Kusmayadi et al., 2018).

\section{METODE PENELITIAN}

\section{Populasi Penelitian}

Populasi yang digunakan dalam penelitian ini adalah semua perusahaan manufaktur yang terdaftar di Bursa Efek Indonesia selama periode penelitian yaitu dari tahun 2013, 2014, 2015, 2016, dan 2017.

\section{Sampel penelitian}

Sampel dalam penelitian ini dipilih dengan menggunakan purposive sampling method dengan kriteria sebagai berikut:

1. Perusahaan yang terdaftar dan menerbitkan laporan keuangan per 31 Desember untuk periode 2013, 2014, 2015, 2016 dan 2017, mempunyai laporan keuangan yang menampilkan laba berturut-turut dan sesuai dengan data yang diperlukan dalam variabel penelitian.

2. Perusahaan manufaktur yang menyajikan laporan keuangan dalam mata uang rupiah (mata uang asing).

\section{Teknik analisa data}

Terdapat beberapa teknik statistik yang dapat digunakan untuk menganalisis data. Untuk mencapai tujuan dalam penelitian ini digunakan 
analisis regresi linier berganda. Metode Analisis regresi linier berganda digunakan untuk menguji Pengaruh Kinerja Keuangan, Market Value Added, dan Ecconomic Value Added terhadap Return Saham pada perusahaan manufaktur terdaftar di BEI. Sebelum analisis regresi linier dilakukan, maka harus diuji terlebih dahulu dengan dilakukan uji asumsi klasik untuk memastikan apakah model regresi digunakan tidak terdapat masalah seperti uji normalitas, uji multikolinearitas, uji heteroskedastisitas, dan uji autokolerasi. Jika terpenuhi maka model analisis layak untuk digunakan.

Adapun Persamaan regresi yang digunakan pada penelitian ini adalah sebagai berikut:

$\mathrm{RS}=\mathrm{a}+\mathrm{b}_{1} \mathrm{NI}+\mathrm{b}_{2} \mathrm{NOPAT}+\mathrm{b}_{3} \mathrm{EPS}+\mathrm{b}_{4} \mathrm{EVA}+\mathrm{b}_{5} \mathrm{MVA}+$

Keterangan:

\begin{tabular}{|c|c|}
\hline $\mathrm{RS}$ & $=$ Return Saham \\
\hline a & $=$ Konstanta \\
\hline b1,b2,b3,b4,b5 & $=$ koefisien regresi \\
\hline NI & $=$ Net Income \\
\hline NOPAT & $=$ Net Operating Profit After \\
\hline $\operatorname{Tax}$ & \\
\hline EPS & $=$ Earning Per Share \\
\hline MVA & $=$ Market Value Added \\
\hline EVA & $\begin{array}{l}=\text { Economic Value Added } \\
=\text { standar error }\end{array}$ \\
\hline
\end{tabular}

\section{HASIL DAN PEMBAHASAN} Statistik Deskriftif

Hasil analisis statistik deskriptif untuk variabel-variabel penelitian tersebut dapat dilihat pada tabel berikut:

Tabel 1 Analisis Statistik Deskriptif

\begin{tabular}{lcccc}
\hline variabel & min & max & mean & $\begin{array}{c}\text { std. } \\
\text { deviatio } \\
n\end{array}$ \\
\hline $\mathrm{RS}$ & $-0,9900$ & 6,6800 & 1,4415 & 1,7544 \\
\hline $\mathrm{NI}$ & 0,0000 & 0,6600 & 0,1009 & 0,0956 \\
\hline NOPAT & 0,0000 & 0,6600 & 0,1064 & 0,0947 \\
\hline
\end{tabular}

\begin{tabular}{|c|c|c|c|c|}
\hline EPS & 1,4500 & $\begin{array}{r}6713,1 \\
900\end{array}$ & 393,9996 & $\begin{array}{r}864,325 \\
0\end{array}$ \\
\hline EVA & 0,0800 & $\begin{array}{r}2230,5 \\
700\end{array}$ & 24,9979 & $\begin{array}{r}158,060 \\
3\end{array}$ \\
\hline MVA & $-0,1500$ & $\begin{array}{r}1418,7 \\
000\end{array}$ & 11,3916 & 95,8586 \\
\hline
\end{tabular}

Valid N

(listwise)

Sumber : data diolah (2019)

Deksriptif statistik yang disajikan pada Tabel 1 analisis statistik deskriptif di atas dapat disimpulkan Return Saham dengan jumlah sampel 242 dari perusahaan manufaktur yang diukur dengan modified Jones models memiliki nilai rata-rata sebesar2,5597dengan standar deviasi sebesar 1,7544 Nilai standar deviasi jika dibandingkan dengan nilai rata-ratanya menunjukkan bahwa standar deviasi lebih besar dari nilai rata-rata. Sedangkan nilai minimum dari variabel Return Sahamadalah sebesar -0,99 dan nilai maksimum sebesar 1,4415 . Hal ini menunjukan adanya peningkatan Return Saham yang terjadi pada perusahaan dalam sampel penelitian ini. Hal ini menunjukan bahwa tindakan Return Saham yang besar yang dilakukan perusahaan dalam melaporkan laba dan kepercayaan investor atas Return yang diperoleh.

\section{Pengujian Hipotesis}

Hasil uji hipotesis dengan menggunakan RegressionWeighted Least Squares (WLS) atau regresi linier tertimbang dapat dilihat pada tebel 2 .

Tabel 2 Hasil Pengujian Hipotesis

\begin{tabular}{lcccl}
\hline Variabel & Koefisien & $\mathbf{t}$ & Sig. & Keterangan \\
\hline Constanta & 0,902 & 4,878 & 0,000 & $\mathrm{H}_{0}$ Diterima \\
\hline $\begin{array}{l}\text { Net } \\
\text { Income }\end{array}$ & 5,915 & 5,385 & 0,000 & $\mathrm{H}_{1}$ Diterima \\
\hline EPS & 0,000 & 1,897 & 0,059 & $\mathrm{H}_{3}$ Ditolak \\
\hline EVA & 0,000 & $\begin{array}{c}- \\
0,073\end{array}$ & 0,942 & $\mathrm{H}_{4}$ Ditolak \\
\hline
\end{tabular}




\begin{tabular}{lcccc}
\hline MVA & $-0,008$ & - & 0,028 & $\mathrm{H}_{5}$ Diterima \\
\hline$R$ Square & 0,163 & & & \\
\hline $\begin{array}{l}\text { Adjusted } \\
R \text { Square }\end{array}$ & 0,148 & & & \\
\hline $\begin{array}{l}\text { Standar } \\
\text { Error of } \\
\text { the }\end{array}$ & 2,09523 & & \\
Estimate & & & \\
\hline$F$ & 11,412 & & \\
\hline Sig & $0,000^{\mathrm{c}}$ & \\
\hline \multicolumn{4}{l}{ Sumber : data diolah (2019) } \\
\end{tabular}

\section{Uji Kelayakan Model}

Uji Koefisien Determinasi $\left(\mathrm{R}^{2}\right)$

Berdasarkan dari hasil uji koefisien determinasi $\left(\mathrm{R}^{2}\right)$ pada tabel 4.7 terhadap model penelitian dengan menggunakan variabel Return Saham yang diperoleh nilai adjusted $R$ squere sebesar 0,163 atau sebesar $16,3 \%$. Dengan demikan, maka dapat disimpulkan bahwa variabel Net Income, EPS, EVA dan MVA bisa menjelaskan $16,3 \%$ variasi variabel Return Saham. Sedangkan sisanya, sebesar $83,7 \%$ dijelaskan oleh faktorfaktor lain di luar variabel penelitian.

\section{Uji Statistik F}

Pengujian ini bertujuan untuk menunjukkan apakah semua variabel independen yang dimasukkan dalam model mempunyai pengaruh secara simultan atau bersama-sama terhadap variabel dependen. Jika nilai probabilitas signifikansi $<0,05$, maka ini menjelaskan bahwa variabel independen dapat secara bersama-sama mempengaruhi variabel dependen.Berdasarkan hasil yang dilihat pada tabel 4.7 menunjukan hasil uji $\mathrm{F}$ dengan nilai $\mathrm{F}$ hitung sebesar 11,412 dengan tingkat signifikansi sebesar 0,000 artinya tingkat signifikan tersebut lebihkecil dari 0,05 atau goodness of-fit sehingga dapat disimpulkan bahwa semua variabel independen yaitu $\mathrm{Net}$ Income, EPS, EVA, dan
MVAberpengaruh secara simultan terhadap Return Saham.

\section{Uji Statistik t}

Uji statistik $t$ bertujuan untuk menunjukkan seberapa jauh pengaruh satu variabel independen secara individual dalam menerangkan variabel dependen. Jika nilai probabilitas signifikansi $<0,05$, maka suatu variabel independen merupakan penjelas yang signifikan terhadap variabel dependen.

Berdasarkan tabel 4.7 hasil pengujian hipotesis 1 dengan menggunakan RegressionWeighted Least Squares (WLS) atau regresi linier tertimbang, seperti terlihat pada Tabel 4.7 variabel Net Income memiliki $\mathrm{t}$ hitung sebesar 5,385 dan tingkat signifikansi sebesar 0,000. Hasil penelitian diperoleh nilai signifikansi sebesar $0,000<0,05$ dan koefisien positif sebesar 5,915, maka disimpulkan bahwa hipotesis 1 (H1) bahwa "Net Income berpengaruh signifikan terhadap Return Saham", diterima.

Hasil pengujian hipotesis 3 yang telah dilakukan seperti terlihat pada tabel 4.7, variabel Earning Per Share memiliki $\mathrm{t}$ hitung sebesar 1,897 dan tingkat signifikansi sebesar 0,059 . Ketentuan pengambilan keputusan hipotesis diterima atau ditolak didasarkan,jika signifikansi lebih kecil atau sama dengan $0,05(\leq 0,05)$, maka hipotesis diterima. Hasil penelitian diperoleh nilai signifikansi sebesar $0,059<0,05$ dan koefisien sebesar 0,000,maka disimpulkan bahwa hipotesis 3 (H3) "EPSberpengaruh signifikan terhadap Return Saham", ditolak.

Hasil pengujian hipotesis 4 yang telah dilakukan seperti terlihat pada tabel 4.7, variabel Economic Value Added memiliki t hitung sebesar -0,073 
dan tingkat signifikansi sebesar 0,942 . Ketentuan pengambilan keputusan hipotesis diterima atau ditolak didasarkan, jika signifikansi lebih kecil atau sama dengan $0,05(\leq 0,05)$, maka hipotesis diterima. Hasil penelitian diperoleh nilai signifikansi sebesar $0,942<0,05$ dan koefisien sebesar 0,000, maka disimpulkan bahwa hipotesis 4 (H4) "Economic Value Added berpengaruh signifikan terhadap Return Saham", ditolak.

Hasil pengujian hipotesis 5 yang telah dilakukan seperti terlihat pada tabel 4.7, variable MVA memiliki $\mathrm{t}$ hitung sebesar -2,214 dan tingkat signifikansi sebesar 0,028. Ketentuan pengambilan keputusan hipotesis diterima atau ditolak didasarkan,jika signifikansi lebih kecil atau sama dengan $(0,05 \leq 0,05)$, maka hipotesis diterima. Hasil penelitian diperoleh nilai signifikansi sebesar $0,028<0,05$ dan koefisien sebesar $-0,008$, maka disimpulkan bahwa hipotesis 5 (H5) bahwa "Market Value Added berpengaruh signifikan terhadap Return Saham", diterima.

\section{Net Income terhadap Return Saham}

Net Income berpengaruh signifikan terhadap Return Saham. Perusahaan yang menghasilkan laba semakin besar, maka secara teoritis perusahaan itu akan mampu membagikan dividen yang semakin besar. Dengan meningkatnya dividen yang diterima oleh investor, maka Return yang diterima oleh investor juga akan meningkat. Hasil penelitian ini menunjukkan kesesuaian dengan teori Sinyal (Signaling Theory) yaitu perusahaan mempunyai dorongan untuk memberikan informasi laporan keuangan pada investor (Wahyunni \& Khairunnisa, 2017). Dorongan perusahaan tersebut ialah sinyal yang digunakan untuk mempengaruhi investor atas kenaikan laba yang berdampak dalam pengambilan keputusan investasi dengan harapan Return saham yang didapat (Septiana \& Wahyuati, 2016).

\section{Earning Per Share terhadap Return Saham}

Earning Per Share tidak berpengaruh signifikan terhadap Return Saham. Dapat dikatakan walaupun tingkat dana investasi yang dihasilkan dari setiap lembar saham biasa yang beredar semakin meningkat belum tentu Return Saham yang akan diterima oleh investor juga akan semakin meningkat, karena informasi yang diberikan tersebut belum memberikan keyakinan terhadap investor akan kenaikan Return Saham.

Hasil penelitian ini menunjukkan bahwa ketidaksesuaian terhadap teori sinyal, dimana informasi laporan keuangan yang diberikan tersebut tidak memberikan dampak atas respon yang diterima oleh investor dalam keputusan investasi, sehingga tidak ada pengaruh signifikan peningkatan lembar saham dengan peningkatan Return Saham yang diterima investor. Jika dilihat pada tabel bahwa nilai standar deviasi lebih besar dari pada nilai rata-rata, maka dapat dikatakan bahwa representasi yang buruk dari keseluruhan data.

\section{Economic Value Added terhadap Return Saham}

Hasil penelitian menunjukkan bahwa variabel economic value addedtidak berpengaruh signifikan terhadap Return Saham. Hasil penelitian ini menunjukkan bahwa economic value added tidak digunakan para investor sebagai acuan besaran Return saham yang diterima. Ketidaksesuaian terhadap teori sinyal, dimana informasi laporan keuangan diberikan kepada investor guna mempengaruhi keputusan 
investasi, akan tetapi hasil penelitian belum mampu memberikan dampak yang signifikan atas economic value added terhadap Return Saham, karena jika dilihat pada tabel dimana nilai standar deviasi lebih besar dari pada nilai rata-rata, maka nilai rata-rata merupakan representasi yang buruk dari keseluruhan data.

\section{Market Value Added terhadap Return Saham}

Hasil penelitian menunjukkan bahwa variabel market value added berpengaruh signifikan terhadap Return Saham. Oleh karena itu, market value added dapat memberikan sinyal kepada investor atas nilai pasar perusahaan terhadap Return Saham, karena market value added mencerminkan ekspektasi pasar terhadap perusahaan di masa datang dan sebagai gambaran seberapa besar tingkat kemakmuran yang diciptakan, sehingga akan memberikan pengaruh kepada investor dalam pengambilan keputusan dengan harapan Return Saham yang dihasilkan perusahaan.

$$
\text { Hasil penelitian ini }
$$

menunjukkan kesesuaian dengan teori Sinyal (Signaling Theory) yaitu perusahaan memberikan informasi laporan keuangan pada investor. Sinyal yang digunakan untuk mempengaruhi investor berdampak dalam pengambilan keputusan investasi dengan harapan Return Saham yang didapat (Nakhei 2016).

\section{PENUTUP}

\section{Kesimpulan}

Penelitian ini dimaksudkan untuk memperoleh bukti empiris mengenai faktor-faktor yang mempengaruhi Return Saham. Faktorfaktor tersebut terdiri dari Kinerja Keuangan (Net Income, Earning Per Share), Economic Value Added dan
Market Value Addedterhadap variabel dependen yaitu Return Saham. Penelitian ini mengambil sampel perusahaan manufaktur yang terdaftar di Bursa Efek Indonesia pada tahun 2013 sampai dengan 2017. Berdasarkan hasil penelitian dan pembahasan, maka dapat diambil kesimpulan sebagai berikut :

1. Net Income berpengaruh signifikan terhadap Return Saham.Semakin tingginya Net Income dalam suatu perusahaan maka semakin besar Return Saham yang didapat.

2. Earning Per Share tidak berpengaruh signifikan terhadap Return Saham. Hasil penelitian ini memberi bukti bahwa Earning Per Share tidak dapat memberikan pengaruhyang signifikan terhadap Return Saham.

3. Economic Value Added tidak berpengaruh signifikan terhadap Return Saham.Hal ini menandakan bahwaEconomic Value Added tidak digunakan para investor sebagai acuan besaran Return Saham yang diterima

4. Market Value Addedberpengaruh signifikan terhadap Return Saham,semakin banyaknya modal investasi dapat berakibat pada makin tingginya tingkat Return Saham.

\section{Saran}

Melalui hasil penelitian ini maka dapat disarankan beberapa hal sebagai berikut :

1. Penelitian selanjutnya disarankan agar memperluas objek penelitian tidak hanya di perusahaan manufaktur tetapi seluruh perusahaan yang terdaftar di Bursa Efek Indonesia.

2. Penelitian berikutnya diharapkan dapat menambahkan variabel independen yang diyakini dapat mempengaruhi Return Saham. 


\section{DAFTAR PUSTAKA}

Amyulianthy, R \& Elsa K., R. (2016). The Effect Of Economic Value Added And Earning Per Share To Stocks Return (Panel Data Approachment.International Journal of Business and Management Invention. 5(2): 815

Hery. (2016). Analisis Laporan Keuangan, Jakarta: PT Grasindo.

Husnan, S \& Pudjiastuti. (2017). Dasardasar teori Portfolio dan AnalisisSekuritas.Yogyakarta.U PP STIM YKPN.

Jariah, A. (2018). Kinerja Keuangan Sebagai Intervening Antara Income Smoothing dan Economic Value Added Dengan EPS. ASSETS : Jurnal Ilmiah Ilmu Akuntansi, Keuangan dan Pajak. 2(2): 1-11

Ibrahim, M., F., Paramita, R, \& Taufiq., M. (2018). Pengaruh NOPAT Dan Goodwill Terhadap Nilai Tambah Ekonomis (EVA) Perusahaan Manufaktur Yang Terdaftar Di Bursa Efek Indonesia Tahun 20142016. Progress Conference. 1(1): 157-166

Kusmayadi, D., Rahman, R., \& Abdullah, Y. (2018). Analysis Of The Effect Of Net Profit Margin, Price To Book Value, and Debt To Equity Ratio On Stock Return.International Journal of Recent Scientific Research. 9(7): 28091-28095

Nakhei, H. (2016). Market value added and traditional accounting criteria: Which measure is a best predictor of stock Return in Malaysian companies. Iranian Journal of Management Studies (IJMS). 9(2): 433-455

Paradiba, L., \& Nainggolan, K. (2015). Pengaruh Laba Bersih Operasi terhadap Harga Saham pada Perusahaan Food and Beverage yang Terdaftar di BEI. Jurnal Riset Akuntansi dan Bisnis. 15(1): 113-124

Rahmawati, A., D. (2016). Pengaruh Laba Bersih dan Arus Kas Terhadap Return Saham di Perusahaan LQ 45. Artikel Ilmiah. Surabaya. Sekolah Tinggi Ilmu Ekonomi Perbanas. 2(5): $1-18$

Septiana, E., F \& Wahyuati, A. (2016). Pengaruh Rasio Keuangan Terhadap Return Saham Pada Perusahaan Manufaktur.Jurnal Ilmu dan Riset Manajemen. 5(1): $1-21$

Sugianto, I \& Nugraha (2017). Analisis Komparatif Metode Rasio Keuangan dan Economic Value Added Untuk Menilai Kinerja Keuangan Perusahaan. Pada Perusahaan terdaftar di Bursa Efek Indonesia (BEI) Periode Tahun 2015-2016.Jurnal Economica. 2(2): 1-15

Wahyunny, F \& Khairunnisa (2017). Pengaruh Faktor Internal dan Eksternal terhadap Return Saham. Pada Perusahaan Sub Sektor Plastik dan Kemasan yang Terdaftar di Bursa Efek Indonesia Tahun 2010-2016.eProceeding of Management : 5(3) : 3376-3381 